\title{
Language Development of slang in the Younger Generation in the Digital Era
}

By :

\author{
Rahmania Maulidiya, Sofia Emanuella Wijaya, Cindy Mauren, Tharissya Pra Adha, Moses \\ Glorino Rumambo Pandin
}

English Language and Literature Department, Faculty of humaniaties, Airlangga University

rahmania.maulidiya-2020@fib.unair.ac.id, sofia.emanuella.wijaya-2020@fib.unair.ac.id, cindy.mauren-2020@fib.unair.ac.id, tharissya.pra.adha-2020@fib.unair.ac.id, moses.glorino@fib.unair.ac.id

\begin{abstract}
Background : Language is the most important thing in life, because it can unite one and other from different regions although different countries. That is why it also has a problem. Language is not just communication but also it becomes an identity for some region or country, as like in Indonesia they have different languages from different regions that make them unique. But unfortunately, most millennial people now choose to use another language as slang that can affect their own language. This study makes to discuss this problem because many people does not matter with this, so we try to let them know that this is important to know because concerning our identity. Purpose : the purpose on this article is to explore a slang language in Indonesia especially in younger generation that affect to Indonesian language in this digital era. Method : This study used a qualitative descriptive method that concerned a questioner as main data, articles then other websites. Results : The result of this study is to realize the importance of language, especially for millennial people who will be the next nation's successor, so that they can understand and also keep their national language. This research is expected to be a reference for people who are interested in studying language then the problem in it.
\end{abstract}

Keywords: Indonesian Language, Online Platform, Slang, Young Generation

\section{INTRODUCTION}

Language is the most important thing in life, both for the country and for the people. Language plays an important role as a unifying nation, therefore it is important to master and know its developer. Language development always occurs every year, and the KBBI (Big Indonesian Dictionary) always experiences additional words. This is inseparable from the role of the younger generation, they use new words among those who are not or have never been in the KBBI. Youth has an important role in language development because youth as the nation's successors should respect and use language so that it does not become extinct. In this case, youth have an interest in the language they use, such as the use of new words that are not yet in the KBBI which they often refer to as slang/slang. They are more likely to use slang/slang than to use good Indonesian. This is motivated by the current digital era, where the younger generation 
spends more time on social media or on other online platforms compared to socializing with the surrounding community. This certainly has a very important influence on their language development, because social media or online platforms can be accessed by many people from every country and circle. This is what triggers the use of foreign words or slang/gal language.

To describe these problems, we will seek and examine various effective solutions to solve these problems. We will also collect data from fellow students to get data and ask their opinions and solutions to this problem. We will take their solutions into consideration in compiling this paper, of course with the help of several sources and articles or journals that we will use to make it more complete and detailed. So that later it can be useful to the wider community who read it, and can also be used as a reference in one's learning or research.

Based on the research that has been done regarding "Language Development of slang in the Younger Generation in the Digital Era" there is a variable "Do you often communicate using slang/slang?" The results of our group's research (2021) show that they rarely use slang in communicating both on social media and in daily activities outside of social media. However, the results of research conducted by Muhammad Ridlo, Yuman Satriyadi, Nadhira Azzahra, Anandita Husnaini Nasution (2021), stated the opposite with the results that $33.24 \%$ used slang very often in communicating and $47.87 \%$ used slang quite often.Second, the variable, "is it necessary to maintain slang?" According to an online survey we performed on the final issue, around 78 percent of those with open questions did not have a problem with the development and existence of slang among young people on social media and in real life. Daily life, whereas research conducted by Muhammad Ridlo, Yuman Satriyadi, Nadhira Azzahra, Anandita Husnaini Nasution (2021), showed different results cited in the conclusions and results of descriptive literature that the existence of slang/slang is not important and is a form of mistake. The findings of research on the development of language in the younger generation in the digital era reveal a variety of research gaps. As a result, more research is needed to explain the causal relationship between the region and the usage of social media in the digital era on language development in the younger generation.

We discuss about the important of language especially Indonesian language as the national language, and also the problem that usually exist in language. This provided the description of language, how important language, then when slang language first used in Indonesia. We explain it in detail, so it can be understand clearly and also get the knowledge from it.

\section{METHODS}

The type of approach we use is a descriptive qualitative and quantitative approach, where we will make several questions or questionnaires which will later be in the form of a google form. We will distribute the questionnaire to Airlangga University students and we will collect the results to be used as data and reference in writing this scientific paper.

The data from this scientific paper comes from the questionnaire that we distributed to Airlangga University students, especially the English language and literature major, because we think they are quite familiar with this problem. However, it is also possible that there are students from other majors who fill out this questionnaire. Therefore, the population is determined by how 
many students fill out this questionnaire which in this case is 23 respondent. Then we use the data and reference material in writing this scientific paper.

The technique we use to collect data is qualitative, where we make a questionnaire in the form of a Google form which is then distributed to fellow students at Universities Airlangga. In addition, we also use several articles, journals and websites for later reference in writing our scientific papers. We have elaborated these two techniques in a coherent and detailed manner so that readers do not feel confused when reading our paper, which we also hope that this paper can be used as a reference for further research.

The analytical technique we use is qualitative technique, where we collect data by distributing a Google form questionnaire containing several questions related to our topic. The respondents we received were Universities Airlangga students from various faculties in Universitas Airlangga.

\section{Results}

In this era of globalization, many things are developing rapidly in Indonesia, one of which is the influence of foreign cultures that enter Indonesia - starting from the use of language, speech styles that vary significantly in pronunciation, and the delivery of words that are not standard anymore. Slang is a variety of informal or non-standard language that is seasonal. Usually, the use of slang is often found among young people. In their daily life, they use slang more often than the standard language that already exists. Slang is commonly used because it is more comfortable and not stiff when spoken. Based on the questionnaires that we distributed, 95.7\% percent of the respondents understood and knew the meaning of slang itself. They also used slang in their daily life because they said it more easy. That is why they choose to use slang language than Indonesian language with standard.

The use of slang is also very flexible in its use because there are no rules for it is to use, so it more simple than Indonesian language. Another reason is using slang when hanging out with friends is very common and easy to communicate, they use slang when hanging out with their friends. However, it turns out that not only when they gather in person, slang is also very often used on social media. If we conclude, slang is the language among those who use it every day. The language is embedded in their lives and cannot be separated, just like the social media they use every day as well as slang. They use social media by using slang, and indeed at first social media also introduced slang among the younger generation. Therefore, slang cannot be separated from social media, because they are one unit. If we look further, this slang language also uses Indonesian, but its use is combined with a foreign language or in a play. That usage is wrong in Indonesian language rules, because a good language in the Indonesian language rules is a language that is in accordance with the linguistics structure. So, slang is not included in Indonesian because it is not in accordance with the rules of the Indonesian language. Slang is also a foreign language that used according to their wishes. Because slang does not have definite structure in its use that is what makes the younger generation like to use it because it is not bound by the rules and they can use it as they wish.

The use of slang continues to increase. According to the data taken, the use of slang continues to grow because they feel that slang is easier to use and easier to understand than standard Indonesian. Therefore, the use of slang in Indonesia is continues to increase, because basically 
most of the Indonesian population are young people and children where they are familiar with social media and even use it every day. As we know that social media is a platform that can be used by everyone from all countries, whit mean that its reach is very wide. This is what triggers the increase in the use of slang, because slang is a mixture of various languages. So, it is very likely that those from outside Indonesia will understand the language and then use it as well. However, although slang continues to increase, it does not mean that most people no longer want to use Indonesian. Many people prefer to use Indonesian when talking to friends or older people. They use Indonesian even though it is not in accordance with the structure and linguistic rules that are good and correct but that right deserves appreciation because they use Indonesian even though they can use slang, and that is something to be grateful for.

\section{Discussions}

Indonesian language is the national language in Indonesia, because Indonesia has a lot of ethnics that have a different culture and also language. That is why they use Indonesian language to unite the different. Although each tribe or region has its own language, they still know and use Indonesian language when they talk to another people that come from different tribe. Indonesian language can be used to the older people too, but make sure that using a good and polite word. If knowing the use of Indonesian language with good and correct, it can be used in various situations. The good and correct Indonesian language is accordance to the structure and rules of the language.

Slang language is the first used in 1980 as a group language. This means that slang just used for group language as their group secret code or cipher. But after the development of time and technology, slang language is growing too. Slang began to be used on social media, initially slang was only used in social media, but continued to grow until now it has been used in everyday life. The used of slang is initially occurred in social media, where this language used to combined languages, such as England and Indonesian language. The merging of these several languages then forms slang, which is used by young people. They used it to communicate with their friend while in chats, social media, or when their hangouts. Slang is the language that they must use when they meet, because according to them this language is the easiest language to use to get along with someone. There are some words that they often use, such as; literally, "santuy", "sabi", "kuy", and etc. the meaning of this word is; literally as English word, this is most frequently word and almost all sentence used this word. "Santuy" is mean relaxed, this is usually used when they are hangout with their friends. "Sabi" in English mean can, this is the most simple used. And then "kuy" is means let go. This word is can be understand by them than good and correct Indonesian language.

In Indonesia today many use slang / slang, especially among teenagers or young people. They use the language in everyday to interact with their friends. The use of this slang / slang language will not eliminate their native language, namely Indonesian, but can fade the values and meanings of good and correct Indonesian. The use of slang or slang has actually been around for a long time in Indonesia, but it's just a different name. In 1980 they also used slang or slang which was formerly known as "prokem" language. The use of this language is also different, where they only use it in a group with the aim that only their group understands, it can be said 
that this slang is used as a symbol or code that only their group understands. Different from now, those who use this slang language usually use Indonesian which is a play on or foreign language that they know through social media which is then used in everyday life.

As we know, social media has become a very important media or platform for teenagers and the younger generation, they can use social media for hours a day. We can say that social media is embedded in the lives of today's young generation. Social media is not completely bad for them, but the emergence of foreign words or slang which then reduces the essence of the value of social media. Social media is the trigger for the emergence of foreign words or slang which is then widely used by young people today. According to them, when they use these words they feel more confident and easy to get along with people, and vice versa if they do not use slang or slang they are considered strange and outdated.

Indonesian language Indonesian is a national language that functions as a unifying language of the nation, as we know that Indonesia has various tribes and cultures where each tribe has a different culture and a different language. Therefore, Indonesian is called the unifying language of the nation because Indonesian can be understood by various ethnic groups in Indonesia. As stated by Arum Putri (2015: 3) who argues that Indonesian as a national language that functions as a communication tool has a role as a transmitter of information. But even though they understand Indonesian, not all know the meaning of good and correct Indonesian and actually not all good Indonesian is correct and not all correct Indonesian is good. Good Indonesian is a language that is appropriate to the situation and conditions and is effective in conveying meaning to the interlocutor. While the correct Indonesian is, Indonesian that is accordance with the rules of the standard language.

As an Indonesian society, it has become a must to be able to use Indonesian properly and correctly. It is appropriate that the use of Indonesian is understood by everyone regardless of race, ethnicity and religion. In fact, the position of Indonesian is very important for the life of the nation and state, as stated in Article 36 of the 1945 Constitution concerning the position of Indonesian as the official state language, an introduction to education, a national level liaison tool and a tool for developing culture and science and technology. So Indonesian should be used both in formal, non-formal and everyday situations. But in fact, the Indonesian language has now been mixed with slang or slang used by some groups, especially teenagers and young people, which have resulted in the loss of the meaning of good and correct Indonesian.

From the questionnaire data we obtained, as many as $95.7 \%$ of respondents know about slang and its use in everyday life. They also said that they often use slang in their daily life when they meet with friends and hangout with them. They also said that they prefer to use slang and Indonesian at the same time, because they think that using slang is easier to understand than using Indonesian properly and correctly. In addition, they also use slang on several platforms on social media. From the data we conclude, $47.8 \%$ use slang on social media such as Instagram, Twitter, Facebook, etc. and 30.4\% use slang in chat platforms such as Whatsapp, telegram, line, etc. $13 \%$ when they hang out and $8.7 \%$ when talking to friends. This means that the use of slang is the most common on social media because of its wider reach, making it easier for them to communicate using the slang language. 
The use of slang continues to increase over time, this is because teenagers or the younger generation prefer to use slang rather than good and correct Indonesian. According to them, the use of good and correct Indonesian is too difficult to understand than using slang. Therefore, they choose to use slang in their daily communication, either directly or indirectly. This increase in the use of slang is not only happening among teenagers or young people, but they also use it when talking to those who are older than them. This of course cannot be separated from the influence of the use of social media which is increasingly being used, and cannot be separated from their lives. Social media is the main trigger for the erosion of the meaning of the Indonesian language, which is where slang was first used and developed in Indonesia. Although we cannot avoid this after all technology is developing.

The slang language is increasing day by day, because young people always use it. Besides it, social media is one of the reasons why this is can happen. As time goes by, digital technology is increasing too. We can access whatever is it in social media, besides it the access of social media is become most large, we can communicate with other people in other country with easily using social media. That is why many people using the social media to communicate with their friend, family, and etc. the using of social media also make us easily to communicate, but there is an impact that caused of it. One of them is slang language, the winder the reach the more develop the use of slang. Because slang is a combination of several languages which are then used as sentences by the younger generation, thus it is not impossible that the use of the language will increase if the reach of social media is expanded. If this is allowed to happen, then the used of Indonesian language will be threatened. They will forget to use good and correct Indonesian, because they are more comfortable or accustomed to using slang. If this is really happens, then Indonesian will lose its existence as national language of the nations.

The emergence of slang cannot be separated from the influence of the use of social media used by teenagers and young people today, whereas as technology develops, social media is increasingly diverse. This is what triggers the excessive use of social media and then triggers the development of slang. As we know, slang was first used through social media, which at first was only used as a language in groups in 1980 in Indonesia and then developed among the community. With the use of social media, this slang language can develop rapidly because of the wide reach of social media. Those who initially did not understand about slang and its use, with social media they began to understand slang and started using it.

With the development of slang, the use of Indonesian is also decreasing. This causes the existence of Indonesian as the national language to begin to erode. If this is allowed to continue, then it is not impossible that Indonesian will be replaced by the slang language. As we know slang is now starting to develop and technology is also growing so that social media will also have a wider reach. This will facilitate the spread of slang in various circles because social media users are not only teenagers and the younger generation, but already include several groups such as adults and children. Those who use social media are certainly familiar with this slang language, because there are so many slang languages used by other social media users. Thus, it is not impossible that they will use the slang language on social media which is then used on a daily basis. So, this will reduce the existence of Indonesian as the national language of the Indonesian state. 
In this era of globalization, many things are developing rapidly in Indonesia, one of which is the influence of foreign cultures that enter Indonesia - starting from the use of language, speech styles that vary significantly in pronunciation, and the delivery of words that are not standard anymore. Slang is a variety of informal or non-standard language that is seasonal. Usually, the use of slang is often found among young people. In their daily life, they use slang more often than the standard language that already exists. Slang is commonly used because it is more comfortable and not stiff when spoken. Based on the questionnaires that we distributed, 95.7\% percent of the respondents understood and knew the meaning of slang itself. They also used slang in their daily life because they said it more easy. That is why they choose to use slang language than Indonesian language with standard.

The use of slang is also very flexible in its use because there are no rules for it is to use, so it more simple than Indonesian language. Another reason is using slang when hanging out with friends is very common and easy to communicate, they use slang when hanging out with their friends. However, it turns out that not only when they gather in person, slang is also very often used on social media. If we conclude, slang is the language among those who use it every day. The language is embedded in their lives and cannot be separated, just like the social media they use every day as well as slang. They use social media by using slang, and indeed at first social media also introduced slang among the younger generation. Therefore, slang cannot be separated from social media, because they are one unit. If we look further, this slang language also uses Indonesian, but its use is combined with a foreign language or in a play. That usage is wrong in Indonesian language rules, because a good language in the Indonesian language rules is a language that is in accordance with the linguistics structure. So, slang is not included in Indonesian because it is not in accordance with the rules of the Indonesian language. Slang is also a foreign language that used according to their wishes. Because slang does not have definite structure in its use that is what makes the younger generation like to use it because it is not bound by the rules and they can use it as they wish.

The use of slang continues to increase. According to the data taken, the use of slang continues to grow because they feel that slang is easier to use and easier to understand than standard Indonesian. Therefore, the use of slang in Indonesia is continues to increase, because basically most of the Indonesian population are young people and children where they are familiar with social media and even use it every day. As we know that social media is a platform that can be used by everyone from all countries, whit mean that its reach is very wide. This is what triggers the increase in the use of slang, because slang is a mixture of various languages. So, it is very likely that those from outside Indonesia will understand the language and then use it as well. However, although slang continues to increase, it does not mean that most people no longer want to use Indonesian. Many people prefer to use Indonesian when talking to friends or older people. They use Indonesian even though it is not in accordance with the structure and linguistic rules that are good and correct but that right deserves appreciation because they use Indonesian even though they can use slang, and that is something to be grateful for.

\section{Conclusion}

Based on the answers from respondents, it can be concluded that $95.7 \%$ of $100 \%$ know what slang is, in the sense that they usually use slang in their daily lives. Then they use slang when they use social media, but they also use slang when they talk to friends and when they hang out. Many young people think that slang is easier to understand than Indonesian. However, not a few 
young people also prefer to use relaxed Indonesian when talking to their interlocutor. They assume that if we speak in Indonesian, it will look polite and they will respect and respect each other. So, the existence of slang is indeed very disturbing the existence of Indonesian. But on the other hand, we cannot prevent it, especially among children and adolescents. Because their psychological development requires them to be recognized in society and one of them is by following the trend of slang. Therefore, the development of slang cannot be prevented but can be minimized if we again increase the existence of the Indonesian language itself.

From the conclusions above, the authors formulate suggestions as follows:

1. There should be more understanding for children and youth.

2. Start from yourself to cultivate the Indonesian language, and improve its existence again.

\section{BIBLIOGRAFI}

1. Riadoh. (2021). Pengaruh Bahasa Gaul Terhadap Penggunaan Bahasa Indonesia di Kalangan Remaja. Jurnal Pendidikan Bahasa Indonesia. Vol 1(1). 51-58.

2. Hilaliyah Hilda. (2010). Maraknya Penggunaan Bahasa Gaul Di Kalangan Pelajar Sekolah Menengah Atas. Jurnal Pendidikan Bahasa dan Sastra Indonesia. Vol 2(1).1326

3. Iswatiningsih, Daroe, Fauzan, Pangestika Fida. (2021). Ekspresi remaja milenial melalui penggunaan bahasa gaul di media sosial. Jurnal Keilmuan Bahasa, Sastra, dan Pengajarannya. Vol 7(2). 476-489

4. Istiqomah Syifah Dina, Nugraha Via. (2018). Analisis Penggunaan Bahasa Prokem Dalam Media Sosial. Jurnal Pendidikan Bahasa dan Sastra Indonesia. Vol 1(5). 665674.

5. Muliawati Hesti. (2017).Variasi Bahasa Gaul Pada Mahasiswa UNSWAGATI Prodi Pendidikan Bahasa Dan Sastra Indonesia Tahun 2016. Jurnal Pendidikan Bahasa dan Sastra Indonesia. Vol 4(2). 43-53

6. Raditya, La Ode Muhammad Sanggah. (2021). Penggunaan Bahasa Gaul (Bahasa Alay) di Twitter. Basindo: Jurnal Kajian Bahasa, Sastra Indonesia, Dan Pembelajarannya. Vol 5(1). 117-123.

7. Budiana Nurchalistiani, Setiyoko Tri Didik. (2020). Implementasi Kalimat Efektif Terhadap Penggunaan Bahasa Gaul. Jurnal KIBASP (Kajian Bahasa, Sastra dan Pengajaran). Vol(4) 1. 61-70.

8. Ridlo, M.S, Yuman, N.A. Nasution,A.H. 2021. Analisis Pengaruh Bahasa Gaul Di Kalangan Mahasiswa Terhadap Bahasa Indonesia Di Zaman Sekarang. Jurnal Kewarganegaraan. 5(2):561-569.

9. Nur Pratiwi Ningsih, L dan Maknun,M.J. (2020). Pengaruh Globalisasi Terhadap Penggunaan Bahasa Indonesia Bagi Masyarakat. Universitas Muhadi Setiabudi. 1(02'), 43-48.

10. Rosnawati, Syukri,A, Badarus Syamsi dan Rizki,A.F. 2021. Aksiologi Ilmu Pengetahuan dan manfaatnya Bagi Manusia. Universitas Pendidikan Ganesha. 4(2):186-194

11. Azizah,A.R. 2019. Penggunaan Bahasa Indonesia dan Bahasa Gaul Di Kalangan Remaja. Universitas Pembangunan Nasional "Veteran' Yogyakarta. 5(2):33-39. 
12. Octorina,I.M, Karwinati,D , Aeni,E.S. 2018. Pengaruh Bahasa Di Media Sosial Bagi Kalangan Remaja. 3 IKIP Siliwangi. 1(5):727-736

13. Sari, Beta Puspa (2015) Dampak Penggunaan Bahasa Gaul Di Kalangan Remaja Terhadap Bahasa Indonesia. In: Prosiding Seminar Nasional Bulan Bahasa 2015. Unit Penerbitan FKIP Universitas Bengkulu, pp. 171-176.

14. Azizah, Auva Rif'at. (2019). Penggunaan Bahasa Indonesia Dan Bahasa Gaul Di Kalangan Remaja. Jurnal Skripsi: Jurnal Pembelajaran Bahasa Dan Sastra Indonesia Universitas PGRI Yogyakarta. Vol 5(2). 33-39.

15. Putri,CIK. 2020. Research publication in language maintenance: an overview of scopus data in 2009-20018. Universitas Airlangga. 4(2):71-79. 